Article

\title{
Critique with Limits-The Construction of American Religion in BioShock: Infinite
}

\author{
Jan Wysocki \\ Institute of Religious Studies, Heidelberg University, Akademiestr. 4-8, 69117 Heidelberg, Germany; \\ jan.wysocki@zegk.uni-heidelberg.de
}

Received: 1 April 2018; Accepted: 3 May 2018; Published: 7 May 2018

\begin{abstract}
Released in 2013, BioShock: Infinite is a blockbuster first-person shooter which explores topics of American nationalism and religion. This article examines how religion is represented within the game and how motifs from American religious history are used to construct its game world. After an overview of the game's production process and a literature review, several specific religious and historical motifs are discussed. Through a dissection of the aesthetic and narrative dimensions of the game, the article analyzes elements of religious history from which the developers of Infinite drew their inspiration, such as the biblical motif of Exodus or the still-popular concept of millennialism. The analysis shows how the game uses familiar but simultaneously transformed American imagery, such as a religiously legitimated American Exceptionalism in which George Washington, Thomas Jefferson, and Benjamin Franklin are worshiped as saintly figures. Infinite plays with popular notions of evangelical religion, mixed with themes related to so-called dangerous cults and sects. In this construction, Infinite strangely vacillates between a biting liberal caricature of religiously fueled nationalism and a nod to widespread moderate mainstream values in which unusual religious movements are negatively portrayed. The article argues that a critique of a mainstream religious movement such as evangelical Christianity is not possible for a multi-billion-dollar industry which is wary of critical topics that may potentially estrange its broad consumer base. In such instances, critique can only be applied to forms of religion that are already viewed as strange by the popular discourse.
\end{abstract}

Keywords: American history; critique of religion; cults; digital games; Evangelicalism; new religious movements; stereotypes

\section{Introduction}

BioShock: Infinite (short: Infinite) is the third installment of an economically and critically successful video game series. It was highly anticipated by both consumers and game critics prior to its long-awaited release in 2013. The high expectations for the game stemmed largely from its lead designer, Ken Levine, whose reputation was that of an auteur of supposedly mature and artful games (Parker 2017, p. 745). His work included positions at Looking Glass Studios and, later, Irrational Games, where he was responsible for the BioShock series. Levine and Irrational Games' contributions to this series were known for their deep atmosphere as well as their attempt to tackle philosophical and political themes within the genre of first-person shooters. The first BioShock (2007), for example, featured a critique of an ultra-liberal political and economic order, in which a society was determined by bare-bones rules and largely by economic power. The game's environment was set in a submarine utopia where an absolute free society, the ultimate meritocracy, was hoped to take shape (Kuhn 2016). In the game, this utopia had collapsed because of intra-societal struggle as well as drug abuse and was the stage for the adventures of the player's quiet main character. 
Both critics and scholars have commented upon BioShock, engaging in lengthy discussions about its artistic quality. The game has been often framed as a validation of the argument that games can be serious art, not merely hollow entertainment products. Players of Bioshock have expressed that the audio-visual style and story, as well as the political and moral themes that it presented, elevated it into a higher sphere of meaningful and thought-provoking cultural products (Clarkson 2009; Parker 2017). Ken Levine has even occasionally been portrayed as the game industry's equivalent of the famous film director Orson Wells (Bissell 2013). The second installment of the series, BioShock 2, presented similar themes as its predecessor; however, failed to merit the level of praise accorded to the first game. This can be partially attributed to the development of BioShock 2 by $2 \mathrm{~K}$ Marin, a different studio then that which produced the first game; the game's production also did not involve Ken Levine. In this regard, Levine's legacy set highest expectations for the third part of the series, Infinite.

Infinite takes the player away from the game's undersea roots and plants her in a sky-based setting, where another form of utopian (or rather dystopian) order has been established. This time, Levine and his team decided to use the game to comment on racism, nationalism, and religious extremism. The antagonist of Infinite is Zachary Hale Comstock, a self-declared prophet who rules over a fictional city in the sky; it is inhabited by an all-white middle and upper class, one which exploits its black, Asian, and Irish working population. This apartheid state rests on religious commandments, focusing on the will of a prophet as well as to the exceptional role of the United States.

Following the release of Bioshock, the game attracted the interest of numerous commentators and was discussed as a vanguard of the games-as-art argument; however, Infinite fared poorly in comparison. Its decidedly neutral stance on politics was regarded as hypocritical, as it depicted the fight against racism and exploitation as negatively as exploitation itself (Pérez-Latorre and Oliva 2017). Additionally, the game was proactively advertised as delivering a "serious, sophisticated political commentary" (Parker 2017, p. 754); however, according to numerous critics, the game failed to deliver on such a promise.

Such themes and their presentation within the game are natural subjects for treatment within the contemporary study of religion. Through an examination of religious motifs in different media, the study of religion can contribute to a fuller understanding of the role of religion within contemporary society. With the meteoric rise of a highly grossing global industry such as digital games, this medium can provide information about shared important themes within society, ranging in perspective from media producers, to audiences who receive and interact with such media, or other media outlets that comment on digital games (Heidbrink et al. 2014, pp. 15-17; Campbell and Grieve 2014).

This article explores Infinite from the perspective of religious studies, which investigates the ways in which religion is constructed in and through media. For example, in the fashion of Cultural Studies as proposed by Russel T. McCutcheon (2007), religion is understood as a system of signs and symbols defined by specific historical and social contexts that convey a special meaning to its actors. One possible route of the study of religion is to determine the perspective of contemporary society regarding religion and how this view developed historically. In this case, the analysis of Infinite is not only an attempt to find out how religion is constructed generally within media but also an examination of how certain events, characters, etc. from religious history are used, combined, and transformed to generate a specific image of religion for a mass media audience.

This article is not the first to consider Infinite as a means by which to explore the study of games or the study of religion. Infinite has been discussed in several game studies publications with topics ranging from its usage of alternate histories (Lizardi 2014), an analysis of its neoliberalist qualities (Pérez-Latorre and Oliva 2017), to its media construction as a "prestige game" (Parker 2017). Several works explores Infinite's themes of utopia and dystopia (Bosman 2014) or its stance on death and redemption with specific regard to the game's recurring theme of baptism (Bosman 2017). Other studies have analyzed how the game offers the opportunity for its audience to discuss religion on internet forums (De Wildt and Aupers 2017). Concurrently, Infinite has been used as an example to convey methodologies for general games research from the point of view of the study of religion 
(Heidbrink et al. 2014). In contrast, this article tackles the question of how the game is positioned in the broader discussion about potential for religious critique. It explores how Infinite depicts themes from different religious backgrounds, critiquing certain religious movements, as well as how the designers of a multi-billion-dollar entertainment product use the critique of religion for the benefit of their product. On the other hand, it also explores how game developers avoided any critique that would have lead to a loss in revenue.

The article surveys the themes of Infinite and analyzes the sources from religious history out of which the designers adopted material to construct Infinite's religiously infused game world. As such, the role that Christian evangelical traditions have had on American history will be illuminated. In particular, the figure of the prophet Comstock will be used as a common thread: how this character encompasses certain stereotypes of evangelical religion as well as narratives about so-called sects, cults, and allegedly dangerous forms of religious organizations. The discussion will explore how, on the one hand, Infinite is upfront in its critical depiction of religiously fueled nationalism; on the other hand, it will be made evident that the game does not so much provide a radical critique of evangelical religion but merely states a mainstream view as to how American values can be perverted through cultic religions. Accordingly, Infinite's critique is part of a common perspective of the American self-conception. It does not so much challenge its audience in its alleged demonstration of the ills of the connection among religion, nationalism, and racism. It rather represents an opinion about religion on which the American discourse already largely agrees. The paper concludes with thoughts about why it is crucial for a multi-million-dollar project like Infinite to avoid any critique of mainstream religion, as the members of such are a possible and hoped-for target audience.

\section{Mirrors of American Religion in Infinite}

To understand the connection of the game to religious imageries as well as its overall connection to religious discourses, it is helpful to work with a methodology that differentiates several dimensions of a game. As proposed by Heidbrink et al. (2014), religion in digital games can be considered according to four different perspectives which comprise the following: aesthetics, gameplay, game world, and gaming culture. Each layer can be considered separately to clearly analyze specific parts of the connection between religious discourses and the studied game. At the same time, those layers should not be viewed in isolation; rather, they are like interlocked cogwheels that make up the comprehensive media product that is a digital game. In this study, those four layers will be utilized to answer the question where and how religious symbols and language is used to construct the game, as well as how the game provides a construct with which to define religion.

\subsection{Aesthetic Representations of Religious Themes}

As an audio-visual medium, digital games present their content through aesthetics: characters and their movement as well as landscapes, architecture, and lighting are visually depicted in the game world; audible components include spoken conversation between characters, the voice of a narrator, sounds of nature, and the overall environment, music, and other sound effects. Infinite's game world is built upon aesthetics which can be associated with specific, identifiable symbols of American Christianity. To provide an overview of the game's aesthetic representation of religion, the following section will focus on the antagonistic character of the prophet Comstock; the section will also discuss other points where the game clearly alludes to the religious symbolism of American Christianity, among other religious movements. Here, specific components of aesthetic depictions will be compared to symbols from religious history and, in so doing, their socio-cultural contexts will be explained.

\subsubsection{The Motif of Exodus and the Chosen People}

In the game, the player steers her avatar (the detective Booker DeWitt) around a city built in the style of 19th century federal architecture. It can be encountered in the form of smaller brick 
buildings as well as neoclassical examples of halls with white columns and domes. This style largely resembles prominent American buildings, such as the White House or the United States Capitol in Washington, D.C., and is meant to point the player towards a historical frame of the early revolutionary and post-revolutionary United States. In the initial minutes of the game, the player is located in a building that could be described as a chapel or church and which is called the Welcome Center. It is filled with water on which small candles are floating. The lighting for the scene is dim, and rays of sunlight cut through the darkness illuminating specific spots of the setting. Within this backdrop, the player can observe several depictions of the prophet Comstock. For example, a stained-glass window shows a scene from the prophet's life. He is painted as a tall, elderly men with long white hair and an impressive white beard. His posture is straight, and he opens his both arms towards the viewer. His left hand is stretched out, towards the people who are surrounding and looking up to him. His right hand points up, to an array of golden clouds from which the roofs of some imposing buildings protrude. A banner is suspended over the whole arrangement, which reads: "And the Prophet shall lead the people to the New Eden".

In this scene, several signs invoke allusions to biblical stories and their American interpretations. First, in a scene in which a white-haired prophet leads a group of people (or even a people) to a heavenly or sky-based city, the banner specifically refers to this city as "the New Eden". The image of leading a people to a place called New Eden, which is situated in a heavenly environment, is an allusion to an intellectual movement associated with early colonial Puritanism and Congregationalist settlers during the late 17th and early 18th centuries (Jue 2008, p. 269). Following the initial phase of colonial settlement in New England, subsequent generations started to think of their ancestors in a quasi-mythological way. In the eyes of colonial theologians such as Increase Mather, Cotton Mather, and Edward Johnson, the actions of their forefathers to leave Great Britain resembled the book of Exodus, in which the Israelites fled from Egypt for a land promised to them by God (McKenna 2007, pp. 33-41; Hankins 2008, p. 4). This mythologization of the early settlers (who had never expressed an identification of their actions with those of the Israelites) had a lasting impact on following generations; for example, this ideology was further popularized by John F. Kennedy's or Ronald Reagan's invocation of John Winthrop's popular speech about "the city upon a hill" (Gaustad and Schmidt 2009, p. 65; Hodgson 2009, p. 2). The leading of a people towards a utopian place by means of a prophetic figure against the backdrop of American history, as it is depicted in the glass painting of the prophet Comstock, precisely conjures associations with popular conceptions of the mythical American past of the first colonies.

\subsubsection{Comstock as Both Mosaic Figure and Cult Leader}

Comstock's image appears throughout the game's unfolding story on posters, statues, cardboard cutouts, and paintings and features always the face of an elderly Caucasian male with long snow-white beard and hair. He is often crowned with a golden aureole that circles his head. This kind of golden halo can be also found on paintings and statues of Christian saints or also on images of other important figures from other religions, e.g., seen in Buddhist iconography. Some of those images show the words "Father Comstock. Our Prophet". The words "father" and "prophet" together with the aureole suggest a strong Christian framework. This is also true for his looks and hair that lean on popular images of the prophet Moses inscribed into popular discourse e.g., through the movie The Ten Commandments (1956).

The player first encounters Comstock through his image, which is displayed on a large canvas via a film projector. Several city guards kneel in front of his hugely projected face and have their heads bent in a submissive fashion. Comstock's role in the city is constructed as both a strong leader and religious figure who commands the absolute loyalty of his subordinates. The (white) populace of the city look up to him as to a father figure who led them to a newfound utopian place and who should be praised for his deeds. The unbreakable loyalty of his guards becomes evident in this scene if the player chooses to shoot these individuals; even when fired upon, the guards do not react but remain still. Such an action provokes a comment from Comstock, who explains to the player that when he 
commands his servants to kneel before his image, they do so without error. Comstock also addresses the player's character, Booker DeWitt, directly and scolds him with a booming and unearthly voice for having failed morally in his life by gambling and drinking.

Throughout the narrative of the game, Comstock is depicted as an unquestionable religious leader whose words are law. He is characterized as having prophetic abilities, which he uses to guide his people and to judge those who have failed in his eyes. In this way, Infinite encourages distinct associations with popular societal imagery, specifically, the discourse about so-called sects and cults. This narrative is strong in American culture but can be found generally throughout Western culture. It entails a certain uneasiness when it comes to religious groups which are led by a charismatic figure or which isolate themselves from general society. This fear of new and non-mainstream religious groups in America was largely sparked when non-Christian organizations, for example, Hinduist and New Age groups, arrived on American shores and gained greater popularity during the rise of the counterculture in the 1960s and 70s. Non-conventional religion was perceived to be a threat to established social norms; soon, rumors of so-called brainwashing and abuse of members of such groups surfaced. Although such fears were undeserved in many cases, anxiety about such groups grew to new heights in the 1990s in association with the prominent cases of murder and suicide within such new religious movements as the Solar Temple, Heaven's Gate, Aum Shinrikyo, and the Branch Davidians (Shupe et al. 2004, p. 198). Those tragedies strengthened the perception that non-conventional religions were often led by strong individuals who required their members submit to their power, even to the point of death. This stereotype has endured and continues to fuel cultural debates regarding certain non-mainstream religions. Infinite takes this stereotype and constructs Comstock's religious movement as a prototypical cliché of a zealous sect or cult. In an interview, Ken Levine also revealed that, in the early development stages for the first Bioshock, there were plans to feature a cult-deprogrammer who is tasked to extract a person from inside a cult group (Remo 2007). This may suggest that Levine is aware of the long-lasting debate regarding cults and that a part of this discussion was deliberately used as building material for Infinite's narrative.

One of the last gameplay scenes in Infinite includes a final confrontation with Comstock. The prophet stands beside a small pool resembling a baptismal font; he appears as an elderly gentleman with a warm, soothing voice. He invites Elizabeth, the companion of the player throughout most of the game, to let him wash her dirty and bloodied hands. After an argument with the prophet, the player's character, Booker DeWitt, kills Comstock on the baptismal font whose last words are "It is finished". This can be interpreted as a reference to John 19:30 which states "So when Jesus had received the sour wine, He said, 'It is finished!' And bowing His head, He gave up His spirit" (New King James Version). This scene paints Comstock as a figure laden with references to the Christian tradition through his bearded Moses-like appearance, the baptismal font, and the reference to the last words of Jesus. The cult analogy is tied firmly to those Christian narratives and suggests to the player that she is confronted with a homicidal quasi-Christian sect.

\subsubsection{Prophetic Visions}

In a section of the game where the player witnesses a pageant, the life of Comstock is presented through oversized cutouts on a festival wagon. The pageant portrays Comstock's early life as a simple farmer. He is shown as being visited by an angel with white robes, who gives him a vision to build a city in the sky. Not only does this depiction point towards Comstock's prophetic and visionary powers but also to a specific part of American religious history. A popular account of a vision of an angel in early American religious history is that found in the Church of Jesus Christ of the Latter-day Saints (LDS), also known as Mormonism. In this story, Joseph Smith, the founder of the LDS, is said to have been visited by an angel in 1823; the angel told him the secret location of an undiscovered biblical text. Smith's religious community grew exponentially and is even today an influential part of the American religious landscape; however, the group remains controversial, particularly with regard to whether it ought to be described as a cult. (Whittaker 2010; Trepanier and Newswander 2012). 
It could be argued that Comstock's vision of an angel is to be understood as a direct reference to Joseph Smith. The intersecting elements of angelic visions, prophetism, and Comstock as a charismatic leader emphasize to the player that she, as well as her avatar Booker, are faced with a non-conventional religious movement, one that is quickly framed as a non-conventional cult with many identifiable Christian elements.

\subsection{Religious Themes in the Broader Narrative and Game World}

This section investigates what the story and the overall world of the game tell the player about religion. Here, the perspective is broadened and more complex interwoven symbolic layers are discussed.

\subsubsection{Millennialism and the Apocalypse}

Comstock's religion is built upon his prophetic visions of a heavenly city for his people as well as the foretelling of the destruction of the world below this city. This apocalyptic worldview has appeared in different forms in religious history in the narrative of millennialism (also referred to as millenarianism). Since the initial settlement of the Puritans on the American continent, the motif of the end of the world remained an important theme in Puritan identity as well as in subsequent movements such as Congregationalism, Revivalism, and Evangelicalism. These end-times were conceived as a drastic but ultimately positive upheaval of the world, after which Jesus would install a divine rule over the people of the world. Several historical conflicts were interpreted by American Protestant contemporaries, such as Jonathan Edwards, as demonstrative of a violent world conflict that would pit good against evil and result in a utopian state (New 2012, p. 42; McKenna 2007, p. 67). The American War of Independence similarly was promoted as the ultimate confrontation between God and Satan's forces, as was the American Civil War eighty years later (McKenna 2007, p. 69).

In Infinite, Comstock not only waits for a final apocalyptic conflict that will lead to a divine period for his followers but is eager to actively destroy the world himself. In the game narrative, Comstock acquires a fictional technology through which he and his followers can lay waste to cities and lands which exist below the floating sky city. A dream sequence in the game depicts a devastating attack on New York. Comstock refers to this literal fire-and-brimstone apocalyptic destruction of the lands below the flying city as Judgement Day, which is another common Christian term for the imagined eschatological event in which God descends from heaven and separates the faithful from the sinners.

This image of the end-times is one of the cornerstones of classical evangelical fundamentalism. As a result of their increased marginalization from public discourse in the early 20th century, conservative Protestant Christians tried to regroup and find common ground to build a strong faith-based community. At the time, many of those conservatives agreed upon the so-called "five points of fundamentalism", which were common markers of their beliefs. One of those five fundamentals was the belief in the Second Coming of Christ on Judgement Day. This idea was made popular by Scottish missionary John Nelson Darby, who devoted himself to interpreting biblical accounts, such as those in the Book of Revelation. His interpretations had a major impact on how the end of the world and the coming reign of Jesus Christ were subsequently understood (New 2012, p. 109; Weber 2005, pp. 19-43). Today, this particular idea endures in evangelical beliefs and has become a frequent topic in popular culture, such as in the long-lasting and best-selling apocalyptic Christian novel series Left Behind, written by Tim LaHaye and Jerry Jenkins (Shuck 2005). But millennialism and an expectation of the end of the world was not only an evangelical narrative. Apocalypticism has also been connected with so-called doomsday cults and their reception by the general public. Several new religious movements who attracted media attention through mass-suicide, violent acts, or other tragic events were also firm believers in one or another form of the end of the world. It is interesting to note the differences in public opinion between the evangelical millennialist beliefs which are tolerated or at least not seen as worrisome and those which (rightly or not) are conceived as threatening. 


\subsubsection{Divinization of American History}

Another part of American culture that Infinite prominently presents is the history of the United States. Through Comstock's biography, the player gets a glimpse into important parts of U.S. history as well as fictional adaptations of that history for the purposes of the game world. One cornerstone of the game's narrative is the founding of the United States and the individuals associated with it, i.e., the Founding Fathers, including George Washington, Benjamin Franklin, and Thomas Jefferson.

In an early section of the game, when the player and her avatar Booker leave the Welcome Center of the flying city, they encounter those three historical figures in the form of giant statues. At the bottom of the statues, several people kneel, fold their hands, and usher prayers, addressing the statues as, for example, "Father Jefferson". The statues are clad in wide robes, each holding a specific item: a key, a scroll, and a sword. In this scene, American historical figures are depicted in a style akin to that of Christian saints (who also are often equipped with specific symbolic attributes, i.e., keys for St. Peter) who are actively worshipped through prayer by their followers. The idea of American Civil Religion, a term coined by scholar Robert N. Bellah (Bellah 1967), is well known, demonstrative of how the American state and its idea are objects of practices and narratives that may be termed religious. However, the depiction of the Founding Fathers as saints goes a step further, by showing not only practices that are not merely analogous to religion but fundamentally are religious.

The topical thread of America and its idea as an object for religious practices and beliefs can be found throughout the game. Comstock and his followers are presented as fanatically devoted to the idea of the nation of America. The founding of the nation is presented more as a myth than as history. In the game's narrative, it is stated that an angel called Columbia originally showed the Founding Fathers a vision by which to construct the United States. Having successfully built this nation, everything went well until the American Civil War. The Civil War can be described as one of the most prominent secular myths of American history, with Abraham Lincoln as the great individual who accepted the risk of a war on American soil to abolish slavery. The game presents a different perspective on Lincoln. Here, Comstock and his followers paint the usually highly regarded 16th President of the United States as a demonic and devilish figure. He is shown as someone who led the nation astray, sowing discord among the citizens. Here, Lincoln's fight against slavery is a fight against the divine foundations of America. The player can observe two paintings in the game in which Lincoln and Washington are leading the armies of the Union and the Confederation, respectively, in the Civil War. Lincoln has horns, glowing red eyes, and a devil's tail (leading the Unionist army), whereas Washington (here, the figure leading the Confederation) wears a white robe and a golden aureole circles his head.

\subsubsection{American Supremacy, Racism, and Its Ties to Religion}

Slavery, or the mistreatment of people who are considered non-white, is an important narrative in the game. The economy of the city is built on the shoulders of black people, Asians, and Irish, whose workforce is exploited. These communities are tolerated but live in the lower depths of the city; they are considered as either moochers or savages who should be happy to be under the strict rule of Comstock. Occasional audio diaries or other clues that can be found in the game feature dialogue about the benefits of the slavery as a system that persisted until the end of the Civil War. It is presented as a just system and as one of the staples of the American nation. In the eyes of Comstock and his followers, America should be a nation of white people who embrace their destiny as supreme rulers over all other peoples in the world. Non-American and non-white people are subordinates who are a threat to the purity of the country. Such sentiments are expressed in the game on a mural where George Washington holds a bell and two stone tablets, an allusion to the Ten Commandments from the Old Testament, and is surrounded by dark and twisted depictions of black people, Jews, Native Americans, Irish, and Asians. On the side of the painting is written: "It is our holy duty to guard against the foreign hordes" as well as "for faith", "for purity", and "for god and country". 
This master race ideology that is represented by Comstock and his followers is built in parts from the principles of the radical nationalistic and racist protestant group of the Ku Klux Klan. This group sought (and still seeks) to rid America from all which is considered foreign influence. The group was first established in the years following the Civil War but gained prominence in the 1920s, when its platforms included advocacy for "one hundred percent American" and stood against all influence from Jews, Catholics, black Americans, or other foreign groups (Lieven 2005, p. 132). This dichotomy between white American Protestantism and foreign non-Protestants which the Klan upheld is used in Infinite to construct Comstock's views on America. It is never clearly stated that Comstock believes in Protestant supremacy; however, the allusions to the ideology of the Klan or similar worldviews are abundant. There is even a radical branch of Comstock's followers who wear the same pointed hoods as the real-world Klan, although the game's rendition makes the hoods violet rather than the infamous white of the Klan.

\subsubsection{Baptism and the "Born-Again" Experience}

Another recurring theme in the game is the ritual of baptism (Bosman 2017). Before the player and her avatar Booker can enter the main stage of the game, i.e., the flying city of Columbia, the player undergoes this ritual of initiation into a religious fellowship. Here, the player is required to let a blind priest in black robes submerge Booker in water so that he might be reborn "in the sweet waters of baptism", as the priest proclaims. The theme of baptism, becoming somebody else, or general personal transformation is frequently mentioned at different occasions throughout the game.

Baptism is a fundamental ritual of Christianity, found within its many diverse traditions. However, Infinite's setting and surrounding narrative suggest that the baptismal ritual mentioned or performed within the game are connected to a specific Protestant evangelical tradition in America. In the evangelical sphere, one of the key cornerstones of this broad denomination of American Protestantism is the individual's personal decision to accept Jesus Christ as one's savior. This narrative of turning willfully towards Jesus is referred to being "born again" and many Americans use this terminology to describe their religious orientation, e.g., labeling themselves as born-again Christians (Hankins 2008, p. 44). This emotional conversion from an individual who is "seeking" versus one who has "found" faith in Jesus was largely established as a narrative in American Protestantism during the First and Second Great Awakening at the end of the 18th and beginning of the 19th centuries. The converted or born-again individual does not necessarily have to be baptized; the extent of the action or ritual depends strongly on the evangelical group with which the individual identifies. However, baptism is a clear marker for this kind of conversion towards the faith evangelical groups promote. In the case of Infinite, a full-body submersion in water is the main depiction of this ritual practice and alludes to evangelical groups such as Baptists or Anabaptists; however, it may also be connected to more marginalized groups, such as the Mormons or Jehovah's Witnesses (which also largely baptize individuals by fully immersing them in water).

The player learns that Comstock also was once baptized and born again. From that moment, he sought to fulfil the prophecy that was sent to him by the angel Columbia: to build a utopian community for those who worship the Founding Fathers, believe in the supremacy of the white race, and want to be pure of foreign and un-American influence.

\subsection{Summary of Evangelical, Nationalist, Millennialist, and "Cultic" Elements}

After having provided an overview of the most prominent points in Infinite's depiction of religious motifs, I would like to summarize the game's overall construction.

Infinite's designers used images from a wide range of American Christianity to construct large sections of the game's aesthetics, narrative, and world. Examples of these general Christian motifs include the figure of the preacher, biblical stories like those in the Book of Exodus, and language that leans on the tone of the Bible. The player can hear gospel songs during gameplay and traverse church-like architecture. The ritual of baptism plays an important role in the game, an action involving 
being submerged in water, which is often connoted with being born again. Here, a more specific form of Christianity comes into play, where Evangelicalism relies heavily on the notion of being born again.

Gradually, this language of evangelical symbolism is transformed into an unusual religious setting. The predominant form of worship in Infinite is directed towards the Founding Fathers of America as well as the prophet Comstock, both of whom are depicted as stone statues or on posters with attributes of Christian saints. The history of the United States is extrapolated into a mythical experience in which the Founding Fathers and the prophet Comstock received a divine command from an angel to build a nation and a city in the sky, respectively.

This American nation is the beginning and the end of the game's predominant religious ideology and is largely defined as one that is exclusively inhabited and ruled by white people, to the exclusion of Jews, Irish, Asians, black people, Native Americans, and other "foreign hordes", as the game tells its player. This foundational belief of the Church of Comstock requires secession from everything considered antithetical to these supremacist values. The American Civil War is seen as the most outrageous treachery against those principles, because it was fought to abolish slavery and take away the white majority's god-given right to rule over non-whites. Here, the basis of evangelical symbolic language is further complemented by the established racist rhetoric of the Ku Klux Klan and other religious-political groups from throughout the history of the United States which have advocated a rule of whites only.

Lastly, this unbearable situation of the post-Civil War United States demanded a change in the eyes of Comstock and his followers. Accordingly, they fled from the (more or less) pluralistic, or at least less bigoted, status quo of the mainland into the clouds, where they built a society in accordance with their values. However, their exodus will only be complete when all else is eradicated in an apocalyptic fashion. Comstock dreams of a Judgement Day in which those who don't follow the doctrine of white supremacy are destroyed in flames. This millennialist expectation is a radical view which has been based on a cornerstone of evangelical belief. It has been transformed into a militant so-called doomsday cult which eagerly awaits the destruction of an evil world and also actively seeks to bring about that destruction.

\section{Critique of Religion}

In almost all cases, religion in Infinite is depicted as something dangerous and inhumane or at least unusual and strange. The player is confronted with followers of a charismatic leader actively preaching white supremacy and ultra-nationalism, ideas which they believe have been legitimized through the divine will of god. The prophet Comstock is painted as a bigoted and cruel antagonist who sends his followers to combat Booker. Both the prophet and his followers embody racist nationalistic and religious ideologies, those which most players probably find repulsive or which at least public discourse agrees to be highly unethical. The fight of the player is also a fight against those racist values that stand anathema to the cultural ideals of the context in which Infinite has been developed (i.e., western, liberal, multicultural).

By fighting the antagonists in the game, the player implicitly fights the kind of religious movement and ideology the followers of Comstock represent. In this game world, religious practice and ideas cannot be separated from Comstock's racist ideology. Accordingly, the question becomes in what way the game expresses a specific critique of religion and, if so, why it is present in the game.

\subsection{Critique of What Exactly?}

It has been shown that religion in Infinite is constructed as fundamentally linked to racist ideology. Both religion in general and, in particular American evangelical religion, are used as the basis for constructing a fictional religion that transports racist narratives and in and of itself represents an enemy against which the player fights. An initial interpretation of religion in the game could be that Infinite presents a critique of the specific religious movement of evangelical Christianity, which is presented as a medium for the promotion of racist ideas and deeds. Such a critique could be constructed as 
Evangelicalism as a nurturer of racism. But this interpretation of Infinite's perspective on religion is too limited. Through an analysis of religious motifs and narratives in the game, one also needs to emphasize what the designers chose not to show as well as themes they left untouched.

The game's inclusion of elements from evangelical Christianity are striking, inserted into the game to construct a religion in the game world that can be easily recognized as iconic touchstones of religion by its players. Baptism, worship, preachers, gospel songs, candles, discussion of god and angels, prophetic visions, and the punishments of the sinful—these iconic elements present a basic framework for the player to realize that she and her avatar have been put into a game world that relies heavily on religious themes. Although evangelical motifs can be found throughout the game, it is interesting which parts of Evangelicalism are absent in Infinite. Two most important parts of American evangelical Christianity are the Bible and the symbol of the cross (Hankins 2008, p. 1). The Evangelical Christians frame the Bible as the true word of God, a holy text which needs to be interpreted in the right way to give meaning for the practitioner's daily life. It is studied in bible classes, consulted to give spiritual guidance and inspiration, and its themes are discussed and disseminated through sermons at church or other religious events. In evangelical thought, the cross stands for the life, death, and resurrection of Jesus. It is not only a reminder of his deeds and his status as the Lord and son of God but also a hopeful sign for the coming end times in which the faithful will be rewarded.

Infinite relies on numerous evangelical motifs in the construction of its game world; however, neither the Bible nor the cross are clearly depicted in the game. There is no single character dialog, note, clue, or other aesthetic or narrative marker which mentions the Bible directly. The only hints to the Bible can be found in the books that lie around in the Welcome Center the player visits at the beginning of the game. But these texts do not display any symbols, such as a cross or the word "Bible" that could indicate its significance. One can find an emulation of a style of language that could stem from the King James Bible on the murals or banners adorning depictions of the prophet, but specific quotations from the Bible are noticeably absent. The only biblical reference is presented when Comstock dies with the words "It is finished". A similar observation can be made for the cross. It is only alluded to as a symbol on the garment of the faux-Ku Klux Klan in the game. The violet hoods are adorned with a long golden dagger which points downwards, resembling the icon of the Christian cross. Apart from this vague allusion, no sign of the cross motif is present in the game.

Another important part of Evangelical Christianity is the figure of Jesus Christ. The entire evangelical narrative landscape depends on his life, words, suffering on the cross, and his resurrection. The evangelical conversion of the born-again experience is a personal turning towards Jesus as one's savior. Infinite sidesteps the topic of Jesus by only mentioning god on select occasions. Terms such as Christ or Jesus are never mentioned, and the worship and prayers that are usually reserved for Jesus in Evangelical Christianity are, in the game, turned towards Comstock, the Founding Fathers, or a vague god figure.

\subsection{Critique of Mainstream Religion as an Economic Risk Factor}

Through a careful examination of the religious motifs that are absent from the construction of religion in Infinite, it appears that there is a deliberate omission of specific religious markers from a religion from which other symbols are easily extracted to build parts of the game world. The question is, why the designers chose not to include other markers, such as the Bible, the cross, and the figure of Christ into their otherwise critical construction of religion.

The interpretation proposed here points towards the economical foundations of the digital games industry, a highly capitalist venture, the mechanics of which are increasingly debated by gaming journalists and scholars (Dyer-Witheford and de Peuter 2009). The digital games industry is one of the highest grossing entertainment industries, with an estimated annual revenue of 26 billion dollars in the European, Middle-Eastern, and African market and 27 billion dollars in the North American market (McDonald 2017). Digital games that are produced for a mass audience tend to incur high development costs. There have been speculations as to Infinite's development costs; industry analysts 
have estimated 100 million dollars (Goldberg 2013). Even if those specific numbers are incorrect, mass market games have frequently cost upwards of 50 million dollars to develop and often involve teams of hundreds who are responsible for the design of this entertainment product (Superannuation 2014). For example, Infinite's design team consisted of over 200 employees (Plante 2014).

With those numbers in mind, it can be argued that a development studio and the publishing company which funds the development will do everything they can to ensure that the revenue of the sold product will surpass its production costs. For this production model to work, nothing in the development process can be left to chance. Game production must necessarily take into account what will appeal to players and critics as well as how to market a game to attract the largest possible audience. The higher the production costs, the bigger the target audience must be. An expensive game will be oriented towards a mainstream audience, one which comprises a range of tastes, social contexts, as well as political and religious backgrounds.

In the case of Infinite, the story of its long and arduous development indicates how important an above-average economic success was for the development studio. Journalistic coverage of the work at Irrational Games reported very high expectations from its publisher Take Two. Several industry commentators speculated that an overall sale of 11 million game copies would not be enough to fulfil investor expectations; subsequently, this was seen as a possible explanation behind the sudden closure of the development studio in 2014 (Alexander 2014; Handrahan 2015). From this perspective, it seems reasonable to assume that, in the five-year development period, those responsible for the game wanted to maximize the likelihood of a success and tailored the game accordingly to appeal to a broad consumer base, consciously avoiding any content that might offend potential customers. Accordingly, Infinite was obliged to cater to an audience which potentially included those who would take offense at the game's depiction of their religious beliefs as underpinning the narrative's antagonists. The evangelical landscape in America is vast. Roughly one quarter of the population of the United States considers themselves as born-again Christian (Hankins 2008, p. 44). From an economic standpoint, developers were unable to neglect this part of the population.

The analysis of Infinite's construction of religion has demonstrated that, although evangelical symbols are used to denote religion in the game, the negative representation of religion does not focus exclusively on Evangelicalism. Negative and off-putting depictions of religion are largely centered on the Church of Comstock's cult-like aspects (in the popular sense of an allegedly dangerous, non-mainstream religion). The game presents no direct critique of a mainstream evangelical family which goes to church on Sundays, potentially are members in one of the big mega-churches and uses its social facilities, listens to Christian pop music, stands for mainstream conservative family values, and upholds a personal relationship with Jesus. The core beliefs of Evangelicals are left untouched by Infinite's negative and stereotypical depiction of religion. When evangelical religious motifs are depicted in the game, they are often connected with the notion that they are being misused by the prophet Comstock and his followers. Mainstream conservative Evangelicals who play the game can observe that, even though familiar themes like baptism, worship, and god are invoked, their beliefs are not the target of ridicule. Mainstream conservatives can see the cultic followers of Comstock as appropriate enemies which need be stopped in their plan to destroy the world.

On the other hand, a more urban liberal demographic is also being catered to. Well known liberal critique and fear of conservative American Christianity nurturing racism and nationalism can still be applied while playing Infinite. Here the ultra-American jingoistic and xenophobic society of Infinite's Columbia can easily be interpreted as a mirror of contemporary America when viewed through the eyes of those who are already highly suspicious of religiously conservatives. In more cynical words one could say that Irrational Games found a way to appeal to different tastes.

Infinite refrains from taking a critical stance on mainstream religion; it also is reluctant to position itself in the political debate it presents to the player. As mentioned above, the game depicts the workers' revolt against racist oppression as negatively as racist oppression itself, an attempt to withdraw from a political statement that could estrange either side of the argument (Alexander 2014; Smith 2016; 
Pérez-Latorre and Oliva 2017). Religion is simply another cultural dimension which is openly depicted in the game but with an attitude that seeks to avoid any conflict with a possible audience.

Interestingly, Infinite is not the only example of a game which tackles the subject of motifs from American evangelical religion and the theme of dangerous cults. Recently, Ubisoft Montreal released the game Far Cry 5 (2018) that also plays with themes of evangelical religion, putting the player in the setting of rural Montana in which a religious movement terrorizes the inhabitants of the fictional Hope County. This group, called Eden's Gate (an allusion to the already-mentioned so-called doomsday cult, Heaven's Gate), is depicted in association with iconic Christian symbols such as small-town churches, cardinal sins, and full-body baptism. Before the release of the game, discussions arose regarding the game as a commentary on current social-political events, such as the recent rise of nationalism and xenophobia in America, which has been partly attributed to the political activity of Evangelical Christians and other conservative groups. However, following its release, game journalists quickly determined that Far Cry 5 was not a critique of American evangelical religion as a supporter of racism and bigotry but a stereotypical depiction of new religious (end-time) movements (Kuchera 2018). The game plays with clichés regarding brainwashing and lunatic doomsday cults which disturb and destroy local communities.

Simultaneously, Infinite uses recognizable evangelical motifs to establish a religious atmosphere for the player but avoids any critique of traditional evangelical religion. The ultra-nationalistic attitudes of Comstock and his army are not fostered by evangelical belief; rather, they are the doings of a cult which distorts American values and religion. The same could be said for Far Cry 5: motifs of rural churches and baptism as well as any potential association with violence and repression are not tied to a critique of evangelical values. Instead, they are presented within the game as a result of the teachings of a deviant cult that stands against conservative American Christian values.

As such, one can observe two examples of how prominent publishers of digital games have attempted to modulate their products to cater to stereotypes already understood by a large audience. Such games appear to criticize aspects of American culture and religion but only superficially. Instead of a commentary on any possible connections of evangelical or overall conservative Christian religion in America to contemporary societal problems, they present to the player the phenomenon of new religious movements, which have already been established in the popular discourse as something deviant and potentially threatening.

Certainly, it would be of use to analyze other mass-market games as to their usage and critique of religion or specific religious traditions to uncover additional or complementary mechanics of the depiction and non-depiction of mainstream religion. On the other hand, it could be also interesting to analyze if smaller studios, with a smaller audience and lower game production costs, use similar methods by which to treat religious topics or whether they have more leeway in the critical presentation of mainstream religious traditions.

Conflicts of Interest: The author declares no conflict of interest.

\section{References}

Alexander, Leigh. 2014. Irrational Games, Journalism, and Airing Dirty Laundry. Gamasutra, February 19. Available online: https://www.gamasutra.com/view/news/211139/Irrational_Games_journalism_and_ airing_dirty_laundry.php (accessed on 30 March 2018).

Bellah, Robert N. 1967. Civil Religion in America. Daedalus Journal of the American Academy of Arts and Sciences 96 : 1-21. [CrossRef]

Bissell, Tom. 2013. Does the Sneaker Have to Matter? An Interview with Ken Levine, the Mind behind BioShock. Grantland, March 26. Available online: http:/ / grantland.com/features/tom-bissell-interviews-ken-levinemind-bioshock/ (accessed on 30 March 2018).

Bosman, Frank. 2014. 'The Lamb of Comstock'. Dystopia and Religion in Video Games. Online-Heidelberg Journal of Religions on the Internet 5. [CrossRef] 
Bosman, Frank. 2017. Accept your baptism, and die! Redemption, Death and Baptism in Bioshock Infinite. Gamevironments 6: 100-29.

Campbell, Heidi A., and Gregory Price Grieve. 2014. What Playing with Religion Offers Digital Game Studies. In Playing With Religion in Digital Games. Edited by Heidi A. Campbell and Gregory Price Grieve. Bloomington: Indiana University Press, pp. 1-21.

Clarkson, Michael. 2009. Critical Compilation. Bioshock. Critical Distance, May 12. Available online: https: / / www.critical-distance.com/2009/06/17/bioshock/ (accessed on 30 March 2018).

De Wildt, Lars, and Stef Aupers. 2017. Bibles and BioShock: Affording Religious Discussion on Video Game Forums. Paper presented at CHI PLAY '17 the Annual Symposium on Computer-Human Interaction in Play, Amsterdam, The Netherlands, November 15-18, pp. 463-75.

Dyer-Witheford, Nick, and Greig de Peuter. 2009. Games of Empire. Global Capitalism and Video Games. Minneapolis and London: University of Minnesota Press.

Gaustad, Edwin, and Leigh E. Schmidt. 2009. The Religious History of America. The Heart of the American Story from Colonial Times to Today, rev. ed. San Francisco: HarperOne.

Goldberg, Harold. 2013. The Nerd as Auteur in BioShock Infinite. New York Times, March 21. Available online: https://www.nytimes.com/2013/03/24/arts/video-games/the-nerd-as-auteur-inbioshock-infinite.html?_r=0 (accessed on 30 March 2018).

Handrahan, Matthew. 2015. Bioshock Infinite Reaches 11 Million Sales. Take-Two CEO Strauss Zelnick Reiterates that Bioshock Is, "a Really Important Franchise for Us". Available online: https: / www.gamesindustry.biz/ articles/2015-06-01-bioshock-infinite-has-sold-11-million-units (accessed on 30 March 2018).

Hankins, Barry. 2008. American Evangelicals: A Contemporary History of a Mainstream Religious Movement. Lanham: Rowman \& Littlefield.

Heidbrink, Simone, Tobias Knoll, and Jan Wysocki. 2014. Theorizing Religion in Digital Games. Perspectives and Approaches. Online-Heidelberg Journal of Religions on the Internet 5. [CrossRef]

Hodgson, Godfrey. 2009. The Myth of American Exceptionalism. New Haven: Yale University Press.

Jue, Jeffrey K. 2008. Puritan millenarianism in Old and New England. In The Cambridge Companion to Puritanism. Edited by John Coffrey and Paul C. H. Lim. Cambridge: Cambridge University Press.

Kuchera, Ben. 2018. Far Cry 5 Review. A Horrible Story Ruins an Enjoyable World. Polygon, March 27. Available online: https: / / www.polygon.com/2018/3/26/17164878/far-cry-5-review-ps4-pc-xbox-one (accessed on 30 March 2018).

Kuhn, Brittany. 2016. The Architecture of Bioshock as Metaphor for Ayn Rand's Objectivism. Gamevironments 5: 132-55.

Lieven, Anatol. 2005. America Right or Wrong. An Anatomy of American Nationalism. Oxford: Oxford University Press.

Lizardi, Ryan. 2014. Bioshock. Complex and Alternate Histories. Game Studies. Available online: http: / / gamestudies.org/1401/articles / lizardi (accessed on 30 March 2018).

McCutcheon, Russel T. 2007. Studying Religion. An Introduction. London: Equinox.

McDonald, Emma. 2017. The Global Games Market Will Reach \$108.9 Billion in 2017 with Mobile Taking 42\%. Available online: https:/ / newzoo.com/insights/articles/the-global-games-market-will-reach-108-9-billionin-2017-with-mobile-taking-42/ (accessed on 30 March 2018).

McKenna, George. 2007. The Puritan Origin of American Patriotism. New Haven: Yale University Press.

New, David S. 2012. Christian Fundamentalism in America. A Cultural History. Jefferson: McFarland.

Parker, Felan. 2017. Canonizing Bioshock. Cultural Value and the Prestige Game. Games and Culture 12: $739-63$. [CrossRef]

Pérez-Latorre, Óliver, and Mercè Oliva. 2017. Video Games, Dystopia, and Neoliberalism. The Case of BioShock Infinite. Games and Culture. [CrossRef]

Plante, Chris. 2014. The Final Years of Irrational Games, According to Those Who Were There. Polygon, March 6. Available online: https://www.polygon.com/2014/3/6/5474722/why-did-irrational-close-bioshockinfinite (accessed on 30 March 2018).

Remo, Chris. 2007. Levine: BioShock Originally About Cult Deprogrammer. Shack News, August 30. Available online: http:/ / www.shacknews.com/article/48731/levine-bioshock-originally-about-cult (accessed on 30 March 2018). 
Smith, Ed. 2016. The Politics of 'BioShock Infinite' Are All the Worse When Revisited in a Heated Election Year. Vice, October 5. Available online: https:/ / www.vice.com/en_us/article/exkvvk/the-politics-of-bioshockinfinite-are-all-the-worse-when-seen-in-a-heated-election-year-130 (accessed on 30 March 2018).

Shuck, Glenn. 2005. Marks of the Beast. The Left behind Novels and the Struggle of Evangelical Identity. New York: New York University Press.

Shupe, Anson, David G. Bromley, and Susan E. Darnell. 2004. The North American Anti-Cult Movement. Vicissitudes of Success and Failure. In The Oxford Handbook of New Religious Movements. Edited by James R. Lewis. Oxford: Oxford University Press, pp. 184-205.

Superannuation. 2014. How Much Does It Cost to Make a Big Video Game? Kotaku.com. Available online: http: / / kotaku.com/how-much-does-it-cost-to-make-a-big-video-game-1501413649 (accessed on 30 March 2018).

Trepanier, Lee, and Lynita K. Newswander. 2012. LDS in the USA. Mormonism and the Making of American Culture. Waco: Baylor University Press.

Weber, Timothy P. 2005. On the Road to Armageddon. How Evangelicals Became Israel's Best Friend. Grand Rapids: Baker Academic.

Whittaker, David J. 2010. Church of Jesus Christ of Latter-day Saints. In The Blackwell Companion to Religion in America. Edited by Philip Goff. Malden: Wiley-Blackwell (Blackwell Companions to Religion), pp. 508-26.

(c) 2018 by the author. Licensee MDPI, Basel, Switzerland. This article is an open access article distributed under the terms and conditions of the Creative Commons Attribution (CC BY) license (http:/ / creativecommons.org/licenses/by/4.0/). 